\title{
Different Types of Benefits and Limitations of Portland Cement
}

\section{Robby Rahim}

Lecturer at Sekolah Tinggi Ilmu Manajemen Sukma, Medan, Indonesia robbirahim@ieee.org

Abstract

Portland concrete is used the world over and used as a fundamental section of strong, mortar, mortar, etc the dry system is used when rough material are commonly hard. This methodology is moderate and its creation is exorbitant. The wet methodology include various action like mixing, expending and pulverizing to deliver the solid.

Keywords: Grinding, Portland cement, clinker etc.

\section{INTRODUCTION}

Concrete is the general term given to the powdered materials which from the beginning have plastic stream when blended in with water or other fluid at any rate has property of setting to a hard-solid structure in two or three hours with changing level of solidarity and holding properties. Concrete is one of the most essential structure materials right now. These are two particular frameworks of amassing concrete. Wet technique minerals are wet ground by adding water to shape a slurry and from that point dried .The dry philosophy minerals are dry ground to outline a powder like substance. Both the procedures are being used and have their own points of interest and limitations. 


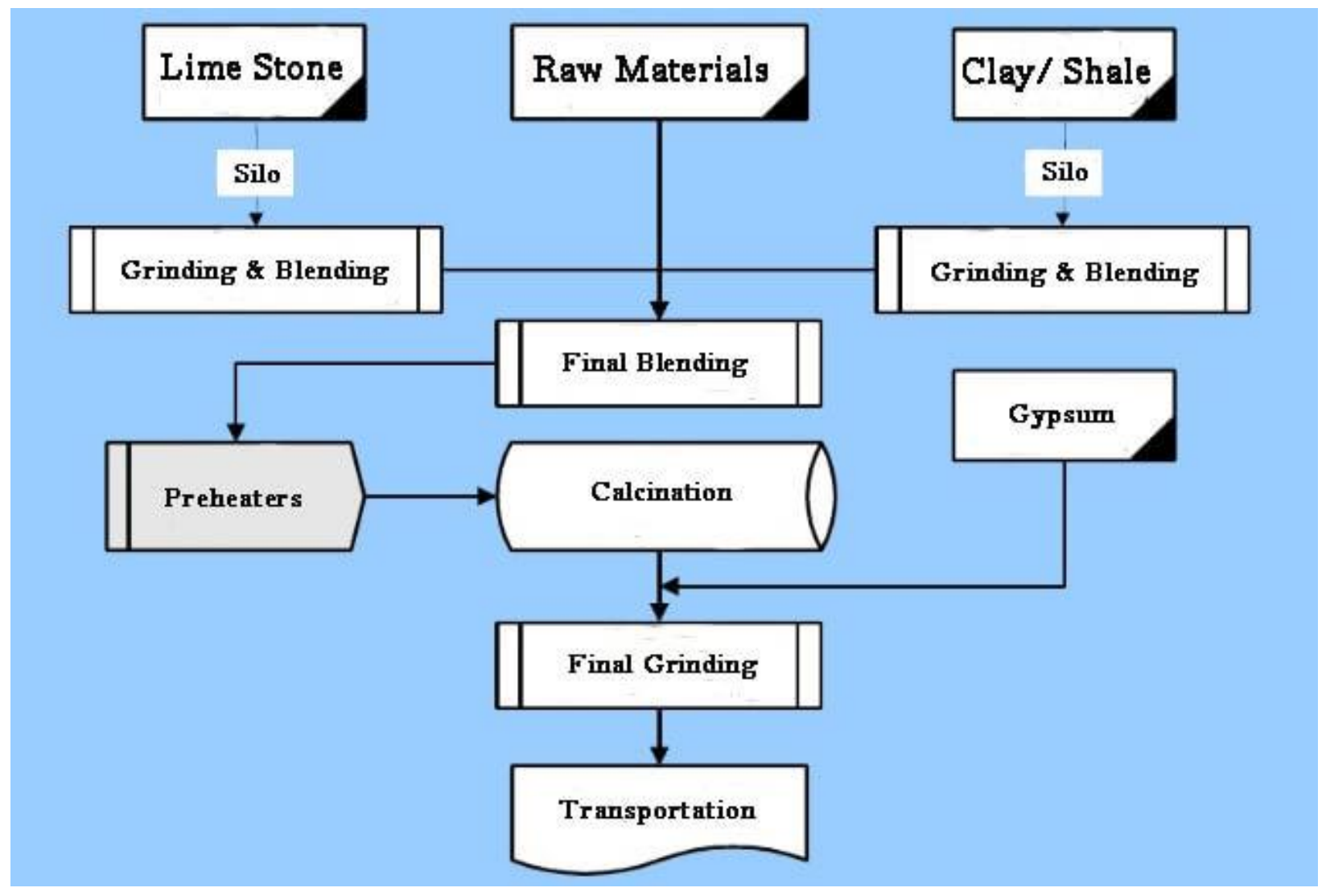

Fig 1 Cement Manufacturing Processes

\section{DRY PROCESS}

At the point when the accessible raw materials are very hard, at that point this procedure is utilized. The raw materials for example argillaceous and calcareous materials are go through in various stages like crushing, drying, reduction of size and mixing. First of all raw materials are broken in quite a while to little parts that be different in size.

After that the squashed materials are dried by heating at an adequately high temperature. It might be done in drying kilns. These materials are then grind by utilizing ball mills and cylinder to diminish the size of materials to discover powder. The finely dried materials are blended in definite extents. The blending might be done either precisely or by pneumatic strategies eg. Pumped under pressure.

Burning and grinding tasks are similar to wet procedure. Aside from the blending of raw materials. In this procedure, the raw materials blended, fined and afterward took care of into kiln though in the wet procedure, the raw materials are squashed independently and afterward legitimately blended in right extent within the presence of water to make a fine thin paste known as Slurry. 


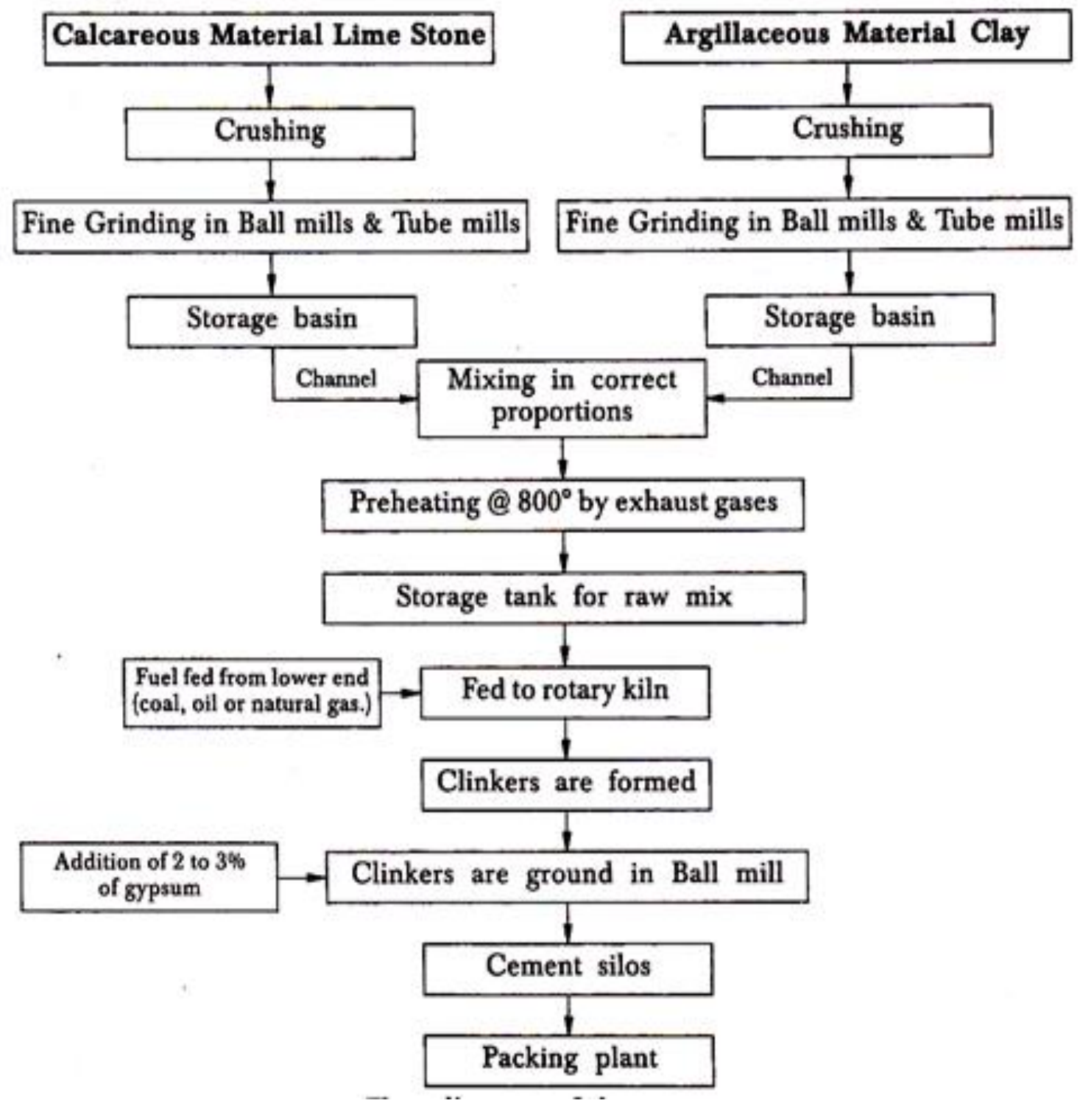

Fig 2: dry process

\section{WET PROCESS}

Wet Process is normal and is all around utilized for the manufacture of cement. In this procedure the raw materials are finely bunch mixed in the structured segment and the mix is brought to the state of free streaming slurry containing $30-40 \%$ water. The slurry is altogether homogenized with the help of compressed air and brought into a rotary kiln. The change gradually descends the kiln because of the revolving movement while an impact of consuming coal is blown from the other end of the kiln. 


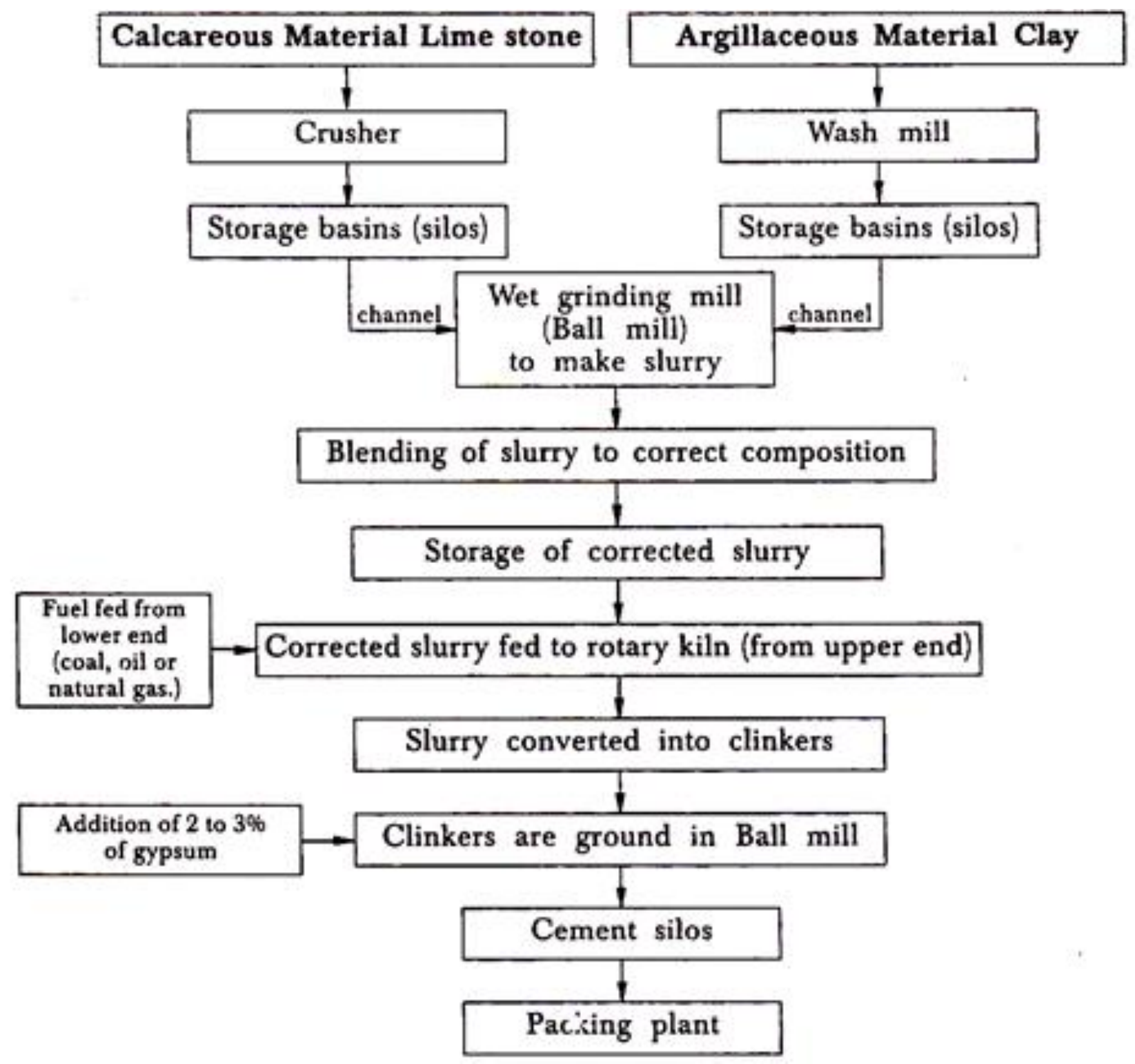

Fig 3: wet process

\section{CONCLUSION}

The main benefit of wet process are low cost of mining and crushing raw materials, the exact control of composition and consistency of the slurry and the cost-effective use of fuel over and done with the exclusion of separated drying operations. The longer kilns necessary in wet process are costly and less approachable to a variable clinker request than the short kilns that can be used in the dry process. 


\section{REFERENCES}

[1] K. Ganesan, K. Rajagopal, and K. Thangavel, "Evaluation of bagasse ash as supplementary cementitious material," Cement and Concrete Composites, vol. 29, no. 6, pp. 515-524, 2007.

[2] S. Sinthaworn and P. Nimityongskul, "Quick monitoring of pozzolanic reactivity of waste ashes," Waste Management, vol.29, no. 5, pp. 1526-1531, 2009.

[3] J. J. Brooks,M. A.M. Johari, andM.Mazloom, "Effect of admixtures on the setting times of highstrength concrete," Cement and Concrete Composites, vol. 22, no. 4, pp. 293-301, 2000.

[4] X. Fu, Z.Wang,W. Tao et al., "Studies on blended cement with a large amount of fly ash," Cement and Concrete Research, vol. 32,no. 7, pp. 1153-1159, 2002.

[5] E.-H. Kadri, S. Kenai, K. Ezziane, R. Siddique, and G. De Schutter, "Influence of metakaolin and silica fume on the heat of hydration and compressive strength development of mortar," Applied Clay Science, vol. 53, no. 4, pp. 704-708, 2011.

[6] V. Indrawati and A. Manaf, "Mechanical strength of trass as supplementary cementing material," Journal of Physical Science, vol. 92, no. 2, pp. 51-59, 2008.

[7] F. M. Lea, The Chemistry of Cement and Concrete, Arnold Publishers, London, UK, 3rd edition, 1970.

[8] J. F. Young, S.Mindess, R. J. Gray, andA. Bentur,TheScience andTechnology of Civil Engineering Materials, Prentice-Hall, Upper Saddle River, NJ, USA, 1998.

[9] H. F. W. Taylor, Cement Chemistry, Thomas Telford, London,UK, 2nd edition, 1997.

[10] S. H. Kosmatka and M. L. Wilson, Design and Control of Concrete Mixtures, Portland Cement Association, Stokie, Ill, USA, 2011.

[11] V. Sata, C. Jaturapitakkul, and K. Kiattikomol, "Influence of pozzolan from various by-product materials on mechanical properties of high-strength concrete," Construction and BuildingMaterials, vol. 21, no. 7, pp. 1589-1598, 2007.

[12] A. Neville, Neville on Concrete, ACI, Farmington Hills, Mich, USA, 2003.

[13] R. Fernandez, F. Martirena, and K. L. Scrivener, "The origin of the pozzolanic activity of calcined clay minerals: a comparison between kaolinite, illite and montmorillonite," Cement and

Concrete Research, vol. 41, no. 1, pp. 113-122, 2011.

[14] C. M. Hanson, "Concrete: the advanced industrial material of the 21st century," Metallurgical \& Materials Transactions A, vol. 26, pp. 1321-1341, 1995.

[15] M. Bediako, S. K. Y. Gawu, and A. A. Adjaottor, "Suitability of some Ghanaian mineral admixtures for masonry mortar formulation," Construction and Building Materials, vol. 29, pp.

667-671, 2012.

[16] S. H. Kosmatka, B. Kerkhoff, and W. C. Panarese, Design and Control of Concrete Mixtures, Portland Cement Association,Skokie, Ill, USA, 14th edition, 2002.

[17] M. S. Mamlouk and J. P. Zaniewski, Materials for Civil andConstruction Engineers, Prentice Hall, Upper Saddle River, NJ,USA, 2006.

[18] T. Punmatharith, M. Rachakornkij, A. Imyim, and M.Wecharatana, "Co-processing of grinding sludge as alternative raw material in portland cement clinker production," Journal of Applied Sciences, vol. 10, no. 15, pp. 1525-1535, 2010. 
[19] D. N. Huntzinger and T. D. Eatmon, "A life-cycle assessment of Portland cement manufacturing: comparing the traditional process with alternative technologies," Journal of Cleaner Production, vol. 17 , no. 7, pp. 668-675, 2009. 